Article

\title{
Studying Sacred Texts as a Pathway to Positive Youth Development: Middle School Students Read Hebrew Bible
}

\author{
Ziva Hassenfeld (D) \\ Mandel Center for Studies in Jewish Education, Brandeis University, Waltham, MA 02453, USA; \\ zrhassenfeld@brandeis.edu or zrhassenfeld@brandeis.edu; Tel.: +1-781-736-5018
}

Received: 14 May 2019; Accepted: 7 June 2019; Published: 12 June 2019

\begin{abstract}
In many religious education classrooms, the meaning of a sacred text is treated as something stable and authoritative. A teacher's job is to transmit that meaning to students. This study reports on a year-long intervention conducted in a seventh grade Hebrew Bible classroom in which students were asked to find their own meaning in the biblical text. The study found that religious text classrooms can offer a unique opportunity to support positive youth development when an effective interpretive community is created.
\end{abstract}

Keywords: Hebrew Bible; Pedagogy; Reader-response theory; religious education

\section{Introduction}

Positive Youth Development theory posits that there are ways to support youth transition into healthy adulthood and that youths' environments have a significant role to play in that process (Bronfenbrenner 1979; King 2008). Leading scholar in the field Pamela E. King explains, "A PYD approach optimistically looks to the systems in which a young person is embedded for potential resources or assets that may promote optimal development within the youth person," (King 2008, p. 56). In its focus on environment, the field of PYD includes a growing body of research that looks at how religious life can facilitate PYD (see, e.g., Arnett 2008; King 2008; Mariano and Damon 2008). King (2008), for example, proposed a conceptual model for how religion can be a catalyst for PYD. She offered three dimensions: the ideological context, the social context, and the transcendent context. The ideological context is the beliefs, values and morals that help a young person to generate a sense of meaning, order and identity. The social context is the community in which a young person performs religious practice. King emphasizes the importance of models and mentors in this social context. And the transcendent context is the awareness that one is part of something bigger. The transcendent context, King explains, can help a young person build a sense of self-worth. Notably missing from King's discussion of religious contexts and PYD, is the educational context.

Coming from the world of religious education, I do not find this gap surprising. Overwhelmingly, religious education, specifically the teaching of sacred texts, is seen as simply a medium through which elements of the ideological context are transmitted; that is, sacred texts are taught to highlight religious beliefs, values and morals (Bielo 2009; Hassenfeld 2017; Peshkin 1988). For example, Genesis 1, Adam's creation, is sometimes taught in order to convey the religious value of respecting every human life.

But sacred text study need not be only a canvas through which to transmit religious values. It can move from passive reception to active religious activity. And as such, it has the potential, as part of a child's religious environment, to contribute significantly to positive youth development. In what follows, I will describe how sacred text study can be taught in such a way that makes it an active religious activity. I will present findings from my own teacher research in which I implemented a 
pedagogical intervention that taught Hebrew Bible as an active religious and interpretive activity. This paper begins with an exploration of conceptions of textual meaning in literary theory and educational research and goes on to introduce the pedagogical intervention, its findings, and the promising implications for PYD.

\section{Meaning and Texts}

Literary theorists have long argued about what constitutes the meaning of a text. In their seminal paper, "The Intentional Fallacy," Wimsatt and Beardsley (1946) challenged the view that the meaning of the text is connected to the intention of the author. Instead, they suggested approaching each text on its own terms without regard to who the author was or what she might have meant. Their approach, part of what came to be called the "New Criticism," posited that a formalized set of tools for analyzing a text could always, in whoever's hands, uncover the "correct" meaning of a text (McCormick 1994).

Reader-response theory challenged this idea. Reader-response theorists introduced the contrasting idea that the meaning of a text depends on who reads it. A reader necessarily brings her own life experiences and perspective to a text. Moreover, this enriches, rather than poses an obstacle to, the reading experience (Eagleton 1983). Literary theorist Louise Rosenblatt (1995) articulated the insight:

What happens [when] reading? The reader, drawing on past linguistic and life experience, links the signs on the page with certain words, certain concepts, certain sensuous experiences, certain images of things, people, actions, scenes. The special meanings and, more particularly, the submerged associations that these words and images have for the individual reader will largely determine what the work communicates to him. (p. 30)

Rosenblatt points out that natural language has a rich history, words have inherent ambiguity and multiple meanings. As readers, we choose from those multiple meanings in accordance with our own associations and experiences, what literary theorist Mikhail Bakhtin (1982) called heteroglossia: that language is "shot through with intentions and accents" (p. 324). To ignore this element of reading, says reader-response theory, is disingenuous.

\subsection{Meaning and the Teaching of Texts}

The reader-response conception of textual meaning has had a strong influence on the pedagogy of text instruction. Literacy scholar Gunther Kress argued that readers' identities and interpretations connect pre-literate "reading" with formal literacy: "All of us act precisely in this fashion in making signs. We never represent the 'whole object' but only ever certain criterial aspects ... " (Kress 1997, p. 11). Kress argued that teachers and adults must attend more carefully to the sign-making practices of children and work to value their nascent interpretive stances. When the toddler points to a picture of a cat and says, "woof," she is communicating her emerging schema of furry animals. These kinds of moments, Kress argues, are opportunities to resist the urge to correct her and say, "No, a cat says, 'meow'." When teaching children to read, validating their responses to the text, their process of meaning making, is more helpful than telling them the right answer.

This insight, that students read texts through the lens of their life experiences and that these readings, while different, are valuable, has animated a whole body of research in literacy education. Socio-cultural research, that accepts this premise, has documented the variety of benefits that come from text instruction that prioritizes students' identities and interpretations in the classroom (Aukerman 2006, 2007, 2008; Chinn et al. 2001; Copenhaver 2001; Eeds and Wells 1989; Lewis 1993; Paley 1986; Reznitskaya et al. 2001). This body of research builds off Lev Vygotsky's foundational work in which he argued that "writing [must] be taught naturally ... [and] should be 'cultivated' rather than 'imposed"" (Vygotsky 1978, p. 118). Vygotsky introduced the idea that formal writing instruction ought to build on what students already bring into the classroom, namely, an appreciation of the importance of symbolic communication. 
Research has shown that students in classrooms that value students' unique interpretive perspectives, advance more quickly than other students in reading comprehension skills (Aukerman et al. 2016; Eeds and Wells 1989); as well as in traditional writing skills (Reznitskaya et al. 2001). Research has also shown that text instruction that prioritizes students' identities and interpretations increases overall engagement and interest (Aukerman 2007; Copenhaver 2001; Lewis 1993; Paley 1986). And, finally, research has shown that text instruction that prioritizes students' identities and interpretations can increase their sense of self-efficacy (Aukerman and Schuldt 2015).

In reality, the sharp distinctions between New Criticism and reader-response theory in literary theory are much less sharp in education. In education, the value of close reading, associated with New Criticism, remains an instructional imperative alongside the reader-response push for prioritizing students' identities and interpretations. In elementary grades, close reading is cultivated through particular reading strategies such as making predictions, constructing, revising, and questioning the meaning of the text as one reads, dealing with inconsistencies or gaps in the text, and attending closely to setting and characters (Duke and Pearson 2002). In secondary grades, close reading is cultivated through more formalized literary interpretation skills such as noticing and interpreting literary devices like symbolism, allusions, and foreshadowing, and "rules of notice" (Rabinowitz 1985, 1987). These skills become a focus of English Language Arts in secondary grades (Levine and Horton 2015). Best practices for the teaching of texts involves developing close reading skills while also making room for students' individual identities and interpretations.

\subsection{Meaning and the Teaching of Sacred Texts}

In religious Jewish education, the reader-response push for prioritizing students' identities and interpretations is overwhelmingly not valued. Research in Jewish sacred text classrooms has documented that most Jewish studies teachers teach sacred texts through the pedagogy of transmission, that is, the teacher tells over to the students a single "correct" and authoritative interpretation of the text (Hassenfeld 2017; Bekerman and Kopelowitz 2008; Galili-Schachter 2011; Katzin 2015; Lehmann 2008; Segal and Bekerman 2009). Close reading, in the New Criticism tradition, is important, but the meaning yielded by close reading has already been assigned by traditional commentators. Bekerman and Rosenfeld (2011), for example, described classrooms in which "students receive continuous explanations by the 'experts' (i.e., teachers)" (pp. 48-49). Bekerman and Kopelowitz (2008), in their study of fourteen different Jewish studies teachers across day schools in different countries, found that these classrooms did not allow for a student to "engage the text critically on his or her own terms" (p. 333).

Researchers in Jewish education have also justified a transmission pedagogy for sacred texts. Devra Lehmann (2008), for example, in her study comparing the text pedagogies of an English teacher and a Jewish studies teacher in one Jewish day school, found that while the English teacher's pedagogy promoted students' independent meaning making, interpretation, and emphasis on their identities, the Jewish studies teacher's pedagogy focused on transmitting authoritative interpretations to the students. Lehmann goes on to justify this stance towards sacred texts by explaining that the Jewish studies teacher "wanted above all to develop Jews who were committed to their tradition," and that "this commitment entailed not only knowledge of the tradition, but also a sense of one's own smallness in relation to its wisdom and authority" (p. 312). In other words, transmitting authoritative interpretations that ignore students' own textual questions and interpretations is appropriate for sacred texts because students' identities, as far as they are individualized and unique, must be de-emphasized in relation to religious tradition.

This study examines a Jewish sacred text classroom from a different perspective. It reports on the findings of an attempt to bring reader-response theory into the study of sacred texts. It asks: What happens when a sacred text teacher moves away from a transmission model of teaching to instead allowing students to bring their own interpretations to the sacred texts? How do students interpret the text given the room to do so? 


\section{Materials and Methods}

This study took place in a religious context, specifically a Hebrew Bible classroom in a Jewish private day school. The classroom in which this research was conducted, unlike the majority of Hebrew Bible classrooms in Jewish day schools (Hassenfeld 2017), took a reader-response approach to text study, emphasizing students' identities and interpretations when studying sacred texts. I know so because I was teacher. As part of a one-year research grant, I became a 7th grade Hebrew Bible teacher in one Jewish K-8 school. While this was my first time teaching in this school, I was familiar with the community and the school. Before beginning my doctoral work, I had taught Hebrew Bible full time in another Jewish day school in the area. I also knew many of the families from the broader Jewish community in which I live and practice. Becoming the teacher gave me pedagogical control so that I could explore the phenomenon of student interpretation of sacred texts in an ideal context. It had the additional privilege of allowing me to get to know each student. As will become clear, getting to know the students added tremendous depth to my understanding of the students as interpreters.

The goal was to implement an approach to teaching Hebrew Bible that would allow students to develop close reading skills, while also making room for them to interpret the text in ways that were "internally persuasive" (Bakhtin 1982). Close reading, a traditional hermeneutic for Jewish Hebrew Bible study, sets it apart from the biblical hermeneutics of other traditions. For example, in evangelical Christianity, the focus of Bible study is often not on analysis of the details of text, identifying and interpreting seeming ellipses and contradictions in the text, but rather, the emotional experience of the reader evoked by the recitation of biblical passages. As Luhrmann (2012) explains, "God talks to you through the Bible ... when evangelicals say that God speaks to them through the Bible, they mean that when they are reading they will have a physical, emotional response to the passage." (pp. 58-59). Contrast this to traditional Jewish Hebrew Bible study in which every biblical verse is accompanied by up to nine classical commentaries that parse out the meaning of each word in the verse and make sense of seeming textual inconsistencies (e.g., if the text discusses the action of two characters but uses a singular conjugation for the verb, classical commentators will point this out and attach meaning to it. Most famously, in Numbers 12:1, the singular feminine conjugation of "spoke" is used in the opening phrase "Miriam and Aaron spoke against Moshe." Classical commentators point this out, and explain that the singular female conjugation indicates that Miriam initiated the bad-mouthing while her brother, Aaron, was a mere bystander.) The Hebrew Bible curriculum developed for this intervention was one in which the traditional Jewish hermeneutic of close reading was cultivated in service of individual interpretation. The two ways of reading worked off one another (see Hassenfeld). See Appendix A for more details about the organization of the class and curriculum.

\section{Creating a Classroom Community of Interpretation}

The school in which this study took place is situated in a particular cultural and religious milieu. The school is traditional. In this school Hebrew Bible is considered sacred. Children receive their first personal copy of the Hebrew Bible in second grade and the entire community gathers to celebrate this milestone. Every Monday and Thursday morning in school, the children hear the week's portion of Hebrew Bible chanted during prayer block. The children begin studying Hebrew Bible the very first week they begin school. At the same time, the religious milieu of the school is progressive and non-doctrinal. In other words, while an intervention that intentionally emphasized students' interpretations may have been pedagogically novel, it was well within the theological bounds of the school.

The curricular and pedagogical intervention implemented in this study cultivated a particular interpretive community (Fish 1980) with very intentional interpretive rules. First, in this classroom there were no authoritative interpretations. Second, the metric of a strong interpretation was not its alignment with tradition, or the historical or cultural context of the biblical text, but rather the ability to ground the interpretation in the words of the biblical text itself. That was the primary interpretive principle, to ground a comment about the text in the language of the text. The grounding in the text 
did not even have to be grammatically correct or fit with the larger plot of the text (identifying such problems with an interpretation and holding students accountable for them was the responsibility of the class, and revising one's interpretation accordingly was encouraged). The primary expectation was that students would use the text to understand the text. For example, if a student wished to argue that Abraham was inconsiderate of his wife Sarah when he went to sacrifice their son Isaac (Genesis Chapter 22), the student was expected to cite indications in the text that Abraham did not discuss the matter with Sarah (e.g., that the biblical text records him leaving "early in the morning" Genesis 22:3, perhaps to avoid Sarah). In other words, the particular constraints placed on textual interpretation in this pedagogical intervention were about process not content. It was this focus on creative and elastic close reading that shaped the interpretive community.

\section{Data Collection}

Data collection took place from fall 2017 to spring 2018. It focused on the whole class text discussions over the course of the entire intervention (one complete school year). Whole class text discussion was the culminating activity of every unit, each of which focused on a single biblical text ranging from 10 to 18 verses. Throughout each unit, students spent time translating the text and reading classical commentaries on the text. The whole class discussion came after the students had been immersed in study of the text for two weeks. Each student brought one question to whole class discussion and the students decided together which questions they wished to pursue in discussion. During discussion, students controlled the discourse. As the teacher, I only stepped in for classroom management and to occasionally summarize student comments. These whole class discussions demonstrated in a situated manner (Greeno 1997) students' development of close reading skills as well as the focus of their textual inquires.

Every whole class discussion was video-recorded and audio-recorded. The transcripts of these discussions were the primary data source in this project. Alongside these transcripts were a number of secondary data sources that served to triangulate (Mathison 1988) the findings. These included my teaching journal, student work, and ongoing assessment of the students' biblical Hebrew decoding skills.

\section{Data Analysis}

Whole class discussions were video recorded and later transcribed. ${ }^{1}$ The transcripts were analyzed for both close reading skills and the nature of students' textual inquiries. It was important to measure both because the hypothesis of the intervention was that developing close reading skills with sacred texts, combined with a reader-response pedagogy, would facilitate students' personal meaning making of the biblical texts. To measure close reading, student comments were analyzed for how they used the biblical text. A text-intensive comment referred to a student comment in which s/he specifically analyzed and cited a word or phrase in the biblical text. In contrast, a non-text-intensive comment referred to a student comment in which s/he did not quote the text. When the students discussed the biblical text, were they using the original Biblical Hebrew? The following considerations guided the codebook: Did they ask questions that took them inside the text or beyond the text? Would they engage in close reading and cite textual evidence in the text? Did they notice and engage the ellipses and ambiguities of the Biblical Hebrew? This was the first metric for looking at text discussion. See Appendix B for the complete code book. To measure the focus of their textual discussions, I turned to discourse analysis (Gee 2014). I looked at the emerging themes in their text discussions and connected them to broader conversations and experiences the students were having outside of the classroom.

1 This study was overseen by the author's academic institution and all video-recording was done with attained parent consent and student assent. 


\section{Results}

Over the course of the year, students began to study the text with increased attention to the details of the text. At the same time, given the space, their textual discussions broached topics that were deeply personal and relevant to their lives. Figure 1 shows the progression of text-intensive student comments throughout the year's whole class discussions.

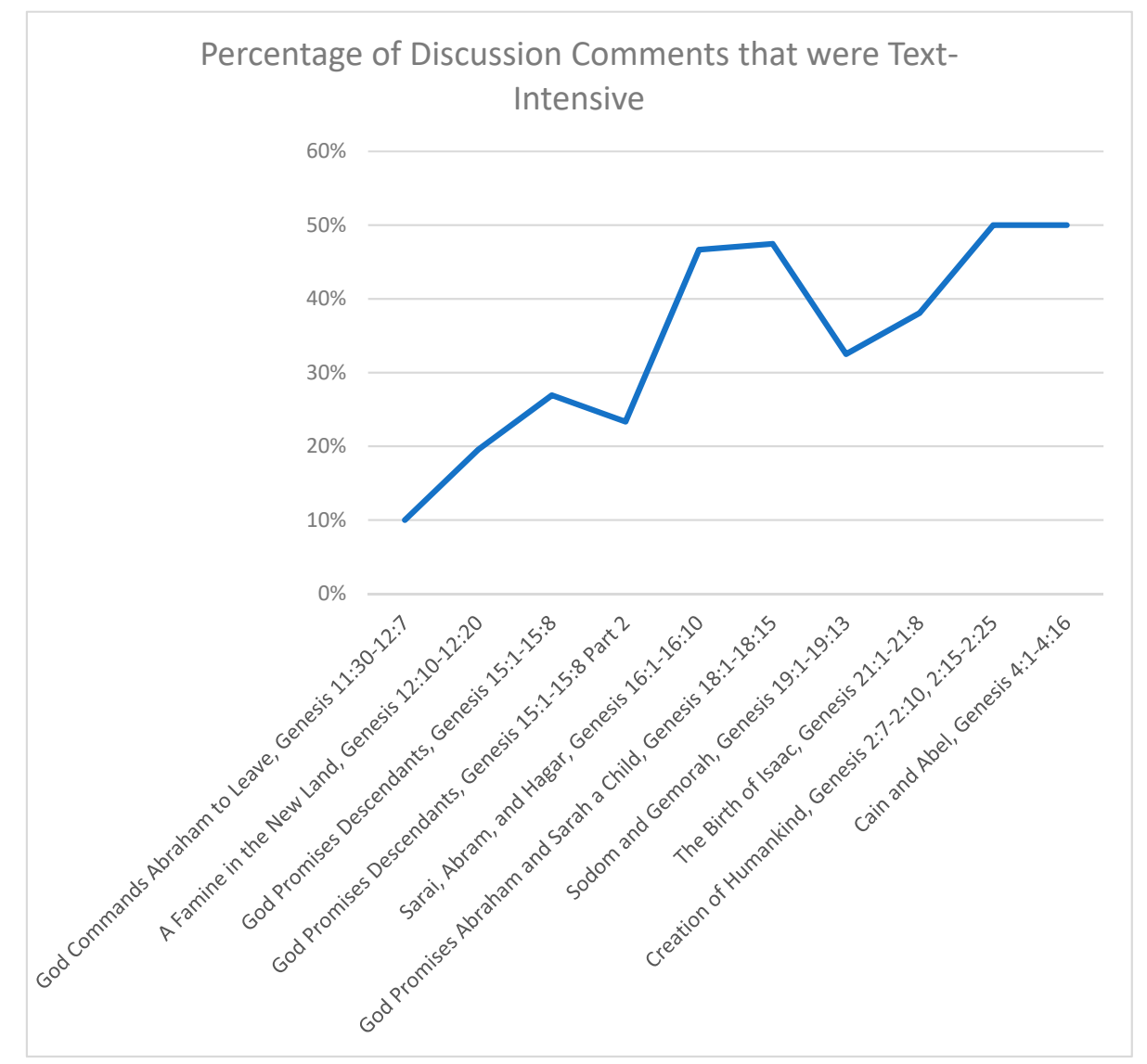

Figure 1. Growth in text-intensive comments during whole class text discussion.

Figure 1 shows on the $\mathrm{X}$-axis the Hebrew Bible text discussed in chronological order, and on the $\mathrm{Y}$-axis the percentage of student comments that were text-intensive. As the year progressed, the students increasingly used the Biblical Hebrew text to talk about the text. Of course, there were fluctuations, but the overall pattern is clear. Students' discussions of texts were increasingly rooted in the language of the texts themselves. It is important to note that the students did not begin the year quoting the biblical text in their discussions. Through the intentional design of this curricular and pedagogical intervention, which involved many different scaffolds and avenues into the text (see Appendix A), the students learned how to engage in rich text-intensive discussions.

As the year progressed, and the students became more comfortable and trusting of the fact that the interpretive space was truly theirs, they began to use the biblical text as a canvas for exploring deeply personal issues. Below I will demonstrate this finding by sharing excerpts of two discussions from the second half of the school year. 


\section{Deep Text Discussion as an Opportunity to Explore Issues that Matter Most}

\subsection{Abraham and Sarah}

In Chapter 18 of the Book of Genesis, three people come to visit Abraham. Abraham welcomes them into his home graciously providing food and rest. These three guests turn out to be angels and deliver a message to Abraham: after years of infertility, Sarah, his wife, will give birth to a baby boy before the end of the year. Sarah overhears the conversation and laughs to herself. God responds to Sarah's laughter with seeming frustration and rebuke. Table 1 provides the complete biblical text.

Table 1. Genesis 18:1-15: Abraham and Sarah are Promised a Child.

1. God appeared to him in Elon Mamre. He was sitting at the opening of the tent in the heat of the day.

2. He lifted his eyes and saw that, behold, there were three people standing near him. He saw and he ran to greet them at the opening of the tent. And they bowed down to the ground.

3. He said, "My lords, if I have found favor in your eyes, please do not pass by from your servant.

4. Let a little water be brought and wash your feet and relax under the tree.

5. I will take fresh bread and you will feed yourselves and after that you can pass by. Because that is the way you pass by your servant." And they said, "Do as you have spoken."

6. Abraham hurried to the tent, to Sarah and said, "Hurry! (Get) three seahs of choice flower! Kneed and make cakes."

7. Then Abraham ran to the herd, took a calf, tender and choice, and gave it to a young lad (who worked for him), who hurried to prepare it.

8. He took curds and milk and the calf that had been made and gave them to them (the three people) and he stood near them under the tree while they ate.

9. They said to him, "Where is your wife Sarah?" He said, "Here in the tent."

10. One said, "I will surely return to you in some time and behold there will be a son to Sarah, your wife." Sarah was listening at the opening of the tent which was behind him.

11. Abraham and Sarah were old, advanced in years. Sarah had stopped having her menstrual cycles.

12. And Sarah laughed to herself saying, 'Now that I am withered, will there be enjoyment with my old husband?'

13. And God said to Abraham, "Why did Sarah laugh saying, 'Is it really believable that I will give birth? I am so old?'

14. Is anything too wondrous for God? I will return to you at this same season next year and to Sarah there will be a son."

15. and Sarah denied it saying, "I did not laugh," because she was afraid. And (God) replied, "You did laugh."

Class discussion began with the students exploring whether Abraham and Sarah knew from the start that the three men were angels, and if not, when, if ever, they figured it out. The discussion soon turned to God's reaction to Sarah's laughter (verses 12-15). One student, Jackie offers her interpretation.

Jackie:I think God doesn't actually seem mad at all. God is just like, 'Why did Sarah laugh?' (18:13) God was genuinely confused.

Jackie, looking at the exact words of the biblical verse, notes that God's initial question is value-neutral. It could be rhetorical and an expression of anger, or it could be a genuine question. Another student asks Jackie to clarify:

Zack: You think God's not mad?

Jackie clarifies and elaborates on her interpretation:

Jackie: Ya. You see God getting mad a lot [in the Bible]. So I feel like if God really was mad, I feel like He wouldn't have made it that Sarah has a kid. But instead He gives Sarah a kid. He just seems genuinely confused.

Jackie provides additional support for her interpretation that God was not really mad at Sarah. She argues that if God had been mad God could have stopped Sarah's pregnancy. God's anger in the Bible is often accompanied with a tangible punishment. The absence of any punishment here is evidence to Jackie that God was not responding with anger. Jackie's classmate, Nir, jumps in. 
Nir: I want to respond to Jackie. I think God could be mad. God is probably a bit hurt by this because Sarah is questioning Him. Sarah should know that even though she doesn't know that that the three people are angels, she knows that God is always watching. So God does have a reason to be mad because she's questioning God.

Nir points out that Sarah is explicitly questioning God's ability to give her a child in her own seemingly rhetorical question (18:12). Nir adds, connecting this question to their previous question in the discussion, that it really does not matter from whom the news of her impending pregnancy came (angels or men) because Sarah should believe, in principle, that God can do anything. Nir's classmate Melanie agrees.

Melanie: That's what I said. That's why I said it wouldn't really matter if she knew they were angels or not because she still knows God promised her kids way back in Lech Lecha (Genesis Chapters 12, 15 and 17).

As this interpretation, that Sarah is at fault for questioning God's ability to do anything God wants, begins to pick up traction in the class, another student, Natan, jumps in.

Natan: I find it crazy that people here are saying that God would be mad that someone's asking a question. I think no one should be mad for asking questions. Asking questions is good, isn't it?

Ali: She's not asking a question, she's doubting Him.

Natan: Okay, so I agree. So why is doubting bad?

Ali: It's like doubting your parents.

Natan: That's how a ton of things start, like in the Holocaust, the Nazis had blind trust, and that's what started it.

Natan cannot let this interpretation go without pointing out the implications of it. For Natan, faulting Sarah for doubting God is tantamount to applauding blind faith. This, Natan points out, is very dangerous. Because blind faith is a way of being in the world. One cannot demand it vis-à-vis God without condoning it vis-à-vis every other doctrine. For Natan, though the interpretation that Sarah was in the wrong for doubting God might fit the words of the text, it did not fit the values surrounding the text.

It is significant that this discussion was happening in the fall of 2017. The U.S. political climate was more hostile and intolerant than it had been in the students' memories and there was a rising discourse around them concerning fake news. Natan may have been attuned into the civic call for debate, questions, and skepticism when he made this comment. He may have been reminded, through the discussion of this biblical story, that doubt can be a moral imperative. He cites the historical example of Nazi Germany and the Holocaust, but the contemporary resonance echo in his comment. This discussion of Genesis 18, the story of Sarah's laughter, became an opportunity for Natan to voice his conviction about the importance of asking questions.

\subsection{Cain and Abel}

The story of Cain and Abel is the story of the first brothers in the Bible. After both brothers make a sacrifice to God and God accepts Abel's but not Cain's, Cain becomes very upset. God tells Cain not to be upset. The two brothers then go into the field, Cain says something (but the biblical text does not tell us what) and, as traditionally understood, Cain gets up and kills his brother Abel. In the class's discussion, this traditional understanding is challenged with a new, unconventional interpretation. Table 2 shows the complete Biblical text. 
Table 2. Genesis 4:1-16: Cain and Abel.

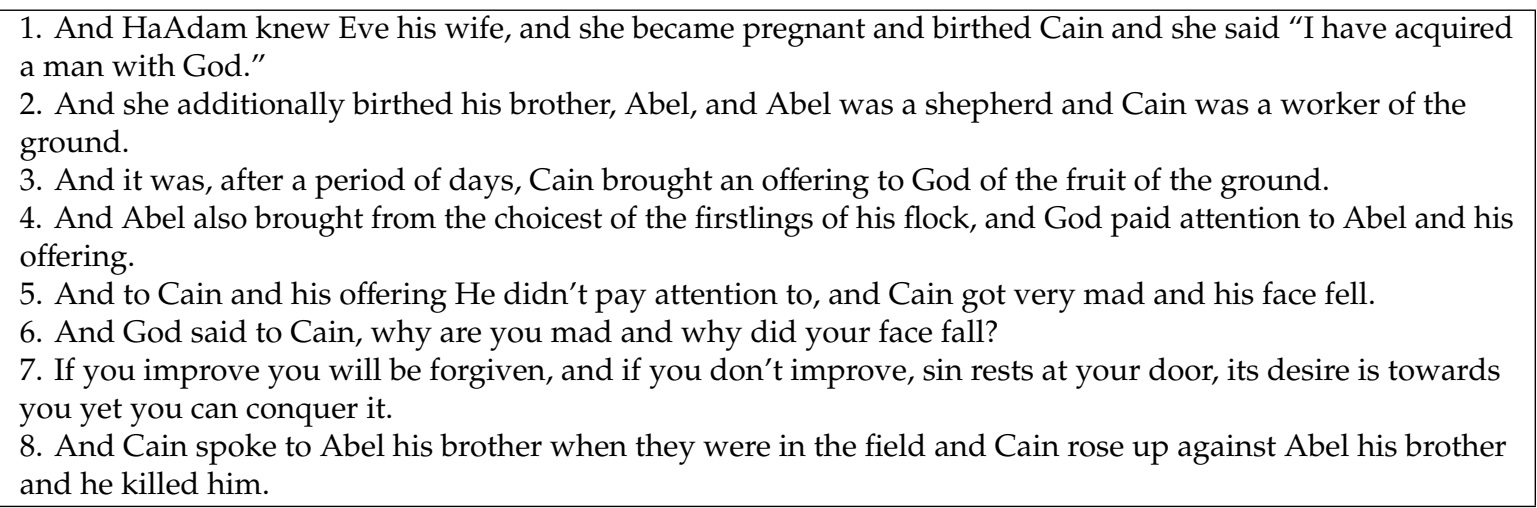

After a few initial comments and questions, one student, Lee, directs the class to a most dramatic moment in the text: the scene of the brotherly confrontation (verse 8). Everything happens very quickly in this scene. The two brothers go out into the field. Cain says something to Abel, the biblical text does not mention what, Abel does not say anything back, and then in a seeming acceleration of emotion, Cain rises up and kills his brother Abel. Lee wonders aloud to the class whether Abel had any idea Cain was going to attack him:

Lee: Okay, I'm going to go that pasuk (biblical verse)... Abel gets killed by Cain, in pasuk chet (eight). I believe Abel had no clue that this would have happened, otherwise he would have said something like, "I don't want to die, don't take me, don't kill me."

In Lee's mind, Abel's silence in the text is evidence of just how unaware he was of his brother's hostility towards him. But Lee's classmate Ben has a different understanding of Abel's silence in the text. In Ben's mind, Abel is very much aware of his brother Cain's hostility towards him and all of its toxicity.

Ben: Lee said, "Why didn't Abel say anything?" Abel didn't say anything because what is there to say in response to bullying?

The way Ben reads the biblical text, Abel's silence is a reflection of Cain's hostility. It is not that Abel does not know the threat his brother poses, but rather that the proper response to Cain's particular form of hostility, bullying, is silence. Ben then explains how he determined that Cain was bullying Abel:

Ben: Then there's something said in the field. And I believe that it couldn't be written in the Torah (Hebrew Bible) because it was so bad. It couldn't be written in the Torah because it's sacrilegious and blasphemous. And then vayehargehu "and he killed him" (4:8), it doesn't mean that he was the one that killed him. It does, but it doesn't mean that he was the one that physically killed him. It means he only came to the realization that he's been doing all of this stuff after the suicide. He realizes vayehargehu "and he killed him (4:8)."

Ben addresses the glaring omission in the biblical text's account of this altercation between the brothers that ends in Abel's death: What exactly did Cain say to his brother in the field before getting up to kill him? Ben has already stated that Cain was bullying Abel, now he elaborates on this interpretation. To make sense of the textual omission, Ben applied his own interpretive principle-Torah Censorship. For him, an omission may signal Torah Censorship and Torah Censorship happens around horrible acts committed against protagonists. Finally, Ben turns the final action in the text ("and he killed him" 4:11) into figurative action-Cain did not literally kill Abel but he drove him to suicide. After presenting his comprehensive and counter-intuitive interpretation of the scene of brotherly confrontation, his classmate, Melanie responds. 
Melanie: Just like overall, I think that based on this text, I think that Abel hasn't done anything wrong, I think that Cain's just taking out his anger on him. Because Cain's mad at God, and he takes all of his anger out on Abel. Like sometimes, when somebody favors somebody else, people get mad at the person that they favor even though they didn't choose to be favored.

Melanie explains that the text is clear that Abel did not do anything to his brother Cain. Only God did. Further, she explains, she was compelled by Ben's analysis of human nature. Melanie reflects that it makes sense to her that Cain would blame Abel for God's dismissal of his sacrifice even though Abel was not to blame. This, in Melanie's mind, fit her adolescent experience of social dynamics.

It is hard to believe that one would read the story of Cain and Abel and see a story of bullying and suicide without coming to the text with bullying and suicide front and center in one's mind. The issue of bullying looms large for most middle school students, but this discussion also happened to be taking place in a particular cultural moment. Besides the bullying that was on full display in the presidential campaign of 2016, the popular TV show, 13 Reasons Why, a show about teen suicide, was currently airing and the court case of Michelle Carter, who encouraged her boyfriend to commit suicide by text message, was dominating the news cycle.

In both of these discussions, the students explored issues that were pressing in their lives, the role of doubt in civic discourse and the dangers of bullying. But in doing so, they did not veer far from the biblical text itself. These students tied their interpretations tightly to the words of the biblical text. They did not choose to confront the topics of doubt and bullying head on. Perhaps they could not. Rather, by discussing the issues through the biblical text, these students provided themselves with a shield that allowed them to open up.

\section{Discussion}

How did the text of the three angels announcing Sarah's pregnancy become a reflection on the role of doubt in civic discourse? Why was the text of Cain and Abel the canvas upon which this small group of students was able to explore bullying? Of course, any answer is a conjecture, data on this question was outside the scope of this research and self-reports from the students may not have been appropriate given the context of this research. But the explanation I wish to offer is rooted in the power of creating this particular interpretive community with this particular text.

Research practitioners before me have documented the ways in which reading and discussing literature can facilitate students' exploration of salient issues of identity and moral questions. For example, Haroutunian-Gordon (2009) writes about how interpretive discussions of literature help students explore "their own ideas and interests," and learn to "tolerate and appreciate others who have difference perspectives," (p. 152). In this sense, the interpretive community created in this Hebrew Bible classroom was just another good text classroom that taught students how to read in a meaningful way.

But I would suggest that there was something unique about reading a sacred text in this way. The students in this study have continually been told throughout their lives that the Hebrew Bible holds deep meaning and relevance. And yet, that meaning has always been presented as something external to the students. Something that need not be constructed in the classroom but rather exists as stable truth to be imported into the classroom by experts. For example, in one popular Hebrew Bible curriculum, LeHavin U'LeHaskel, there is a section in each lesson plan titled "practical application" that outlines the meaning students should draw from the text for their lives. For Genesis 16, where Abraham conceives with Hagar, Sarah's maidservant, the lesson plan explains, "Practical application: When things happen to a person we can't understand why. ONLY HASHEM (God) KNOWS WHY AND HE KNOWS WHAT IS BEST FOR US," (capitalization from the quote).

The interpretive community created in this Hebrew Bible classroom gave students the opportunity to find the text's meaning for themselves, and the tools to do so. The interactive effect of the cultural significance of the Hebrew Bible combined with a method of close reading and open-ended interpretation allowed students to develop personally relevant and meaningful readings of the text The 
next step in this research is to follow these students and see how this sort of religious text classroom affects their overall religious development.

\section{Conclusions}

Religious text classrooms offer a unique opportunity to support positive youth development (PYD). We know text discussion can be a canvas for exploration of the most significant issues in readers' lives. Likewise, we know that religious practice can be a powerful resource for PYD. When text discussion is integrated into religious practice, the meaning that emerges from discussion of the text becomes imbued with religious significance. The discovery that the very sacred texts central to a youth's religious environment can authentically speak to the issues that matter most to her is a powerful discovery. To compound that discovery with the knowledge that such meaning emerged from traditional Jewish hermeneutics amplifies the impact. Scholars of PYD agree that formation of identity is essential to the positive development of a young person. Text discussion is a space in which humans can, in dialogue with the text and their co-readers, uncover insights into their life experiences. Religious practice is a space where humans affirm the value of life and define the guiding principles through which they hope to live their lives and make sense of their experiences. When the two are brought together through a reader-response text pedagogy in religious text classrooms, an important, and yet unexplored, opportunity for identity formation emerges.

The irony is just how uncommon reader-response pedagogy is in religious education. Of course, the reasons for sticking with a transmission pedagogy where authoritative interpretations and meanings are delivered, are clear. It is safe. It inducts students into the well of tradition, an important value of religious education. And it is pedagogically easy. Handing over textual meaning to students can often mean, as seen above, allowing the text to be taken in unconventional directions. But if the cost is interpretive innovation, the reward is giving students the gift of religious significance and meaning relevant to their own lives.

Funding: This research was funded by The Sylvia and Moshe Ettenberg Research Grant in Jewish Education.

Conflicts of Interest: The author declares no conflict of interest.

\section{Appendix A. Organization of the Curricular and Pedagogical Intervention}

The curriculum designed for this intervention study consisted of eight texts from Genesis (Chapters 1-22). The texts were all drawn from the school's mandated 7th grade Hebrew Bible curriculum. The curriculum followed a cycle of seven to eight lessons for each text:

- $\quad$ Exposure to necessary background

- $\quad$ Previewing vocabulary and grammatical constructs

- $\quad$ Read-aloud

- Pair translation

- Question generation

- Close reading and Reading strategies

- Performance

- Whole class discussion

Table A1. A Typical TLC Unit.

\begin{tabular}{cll}
\hline Class & Literacy Component & Class Activities \\
\hline \multirow{3}{*}{1} & $\bullet \quad$ Preview Vocabulary \\
& - Whole Class Read-aloud \\
& $\bullet \quad$ Translate in Pairs \\
& $\bullet \quad$ Whole Class Read-aloud and Go Over Translation \\
\hline
\end{tabular}


Table A1. Cont.

\begin{tabular}{|c|c|}
\hline 2 & $\begin{array}{ll}\text { - } & \text { Grammar Review Activities } \\
\text { - } & \text { Whole Class Read-aloud with Translation } \\
\text { - } & \text { Translate in Pairs } \\
\text { - } & \text { Whole Class-Go Over Translation } \\
\text { - } & \text { First Round of Student Questions }\end{array}$ \\
\hline 3 & $\begin{array}{l}\text { - Whole Class Read-aloud with Translation and Student Questions } \\
\text { - } \quad \text { Close Read Work in Pairs }\end{array}$ \\
\hline 4 & $\begin{array}{l}\text { - } \quad \text { Quick Whole Class Read-aloud } \\
\text { - } \quad \text { Commentator Work in Pairs }\end{array}$ \\
\hline 5 & - $\quad$ Prepare Performances \\
\hline 6 & $\begin{array}{l}\text { - } \quad \text { Perform Performances } \\
\text { - } \quad \text { Discussion of Performances } \\
\text { - Silent Write- Students Prepare their Questions for Whole Class } \\
\text { Text Discussion }\end{array}$ \\
\hline 7 & - Whole Class Text Discussion Part I \\
\hline 8 & - Whole Class Text Discussion Part II \\
\hline
\end{tabular}

\section{Appendix B. Discussion Transcript Code Book}

Rules for dividing classroom transcripts into discrete talk turn episodes:

1. An episode comprised of a single student comment.

2. If a student used his/her talk turn to make two distinct comments, each comment was counted as its own episode.

3. If I asked a clarifying question after a student comment, the student's clarification was included in the same episode as an extension of the comment.

Table A2. Codebook for Text-Intensivity.

\begin{tabular}{lll}
\hline Code & Description & Example \\
\hline Text-Intensive: Word Analysis & $\begin{array}{l}\text { Student comment specifically } \\
\text { analyzes and cites a word in the } \\
\text { biblical text. }\end{array}$ & $\begin{array}{l}\text { Jake: I think that Cain said to Abel, "brother" } \\
\text { instead of "my brother" which woke him up, } \\
\text { and then he killed him. }\end{array}$ \\
\hline $\begin{array}{ll}\text { Text-Intensive: Verse Analysis } \\
\text { Student comment quotes the text } \\
\text { and analyzes the quote in the } \\
\text { context of the class discussion. }\end{array}$ & $\begin{array}{l}\text { Eva: Okay so this is a really weird theory and } \\
\text { I don't really believe it, but someone said } \\
\text { yesterday that this is all a test. I think it is } \\
\text { true, and Abel is probably an angel or } \\
\text { something, because it says "vatahar vateled," } \\
\text { ("and she conceived and she gave birth") but } \\
\text { then in pasuk bet (verse 2) when she gives } \\
\text { birth to Abel it never says that she conceived. }\end{array}$ \\
$\begin{array}{ll}\text { Text-Intensive): Specific Reference } \\
\text { in Text }\end{array}$ & $\begin{array}{l}\text { Student comment references a } \\
\text { specific event from the text but } \\
\text { does not quote the text. }\end{array}$ & $\begin{array}{l}\text { Sam: I don't think Avraham was going to go } \\
\text { through with this because it just says he was } \\
\text { taking out the knife it doesn't say he was } \\
\text { raising it above Yitzhak... the artwork is } \\
\text { an imagination. }\end{array}$ \\
\hline $\begin{array}{l}\text { Text-Expansive (Not } \\
\text { Analysis Broadly }\end{array}$ & $\begin{array}{l}\text { Kate: I think the test between Avraham and } \\
\text { God there's kind of two ways-does he have } \\
\text { enough faith in God but also does he have } \\
\text { enough faith in his son. This is more of an } \\
\text { Avraham son story than an Avraham } \\
\text { God story. }\end{array}$ \\
\hline
\end{tabular}




\section{References}

Arnett, Jeffrey Jensen. 2008. From "word food" to "infinite bliss": Emerging adults' views of life after death. In Positive Youth Development and Spirituality: From Theory to Research. Edited by Richard Lerner, Robert Roeser and Erin Phelps. West Conshohocken: Templeton Foundation Press, pp. 231-46.

Aukerman, Maren. 2006. Who's afraid of the big “bad answer”? Educational Leadership 64: 37-41.

Aukerman, Maren. 2007. When reading it wrong is getting it right: Shared evaluation pedagogy among struggling fifth grade readers. Research in the Teaching of English 42: 56-103.

Aukerman, Maren. 2008. In praise of wiggle room: Locating comprehension in unlikely places. Language Arts 86: $52-60$.

Aukerman, Maren, and Lorien Chambers Schuldt. 2015. Children's perceptions of their reading ability and epistemic roles in monologically and dialogically organized bilingual classrooms. Journal of Literacy Research 47: 115-45. [CrossRef]

Aukerman, Maren, Paolo Martin, John Gargani, and Richard McCallum. 2016. A randomized control trial of Shared Evaluation Pedagogy: The near-term and long-term impact of dialogically organized reading instruction. L1 Educational Studies in Language and Literature. (Special issue International Perspectives on Dialogic Theory and Practice). Available online: http://dx.doi.org/10.17239/L1ESLL-2016.16.02.02 (accessed on 12 June 2019).

Bakhtin, Mikhail Mikhaîlovich. 1982. The Dialogic Imagination: Four Essays. Edited by Michael Holquist. Translated by Caryl Emerson, and Michael Holquist. Austin: University of Texas Press.

Bekerman, Zvi, and Ezra Kopelowitz, eds. 2008. The unintended consequences of liberal Jewish schooling: A comparative study of the teaching of Jewish texts for the purpose of cultural sustainability. In Cultural Education-Cultural Sustainability: Minority, Diaspora, Indigenous and Ethno-Religious Groups in Multicultural Societies. New York: Routledge, pp. 323-42.

Bekerman, Zvi, and Sue Rosenfeld. 2011. Culture: Restoring culture to Jewish cultural education. In International Handbook of Jewish Education. Edited by Helena Miller and Alex Pomson. Dordrecht: Springer, pp. 47-62.

Bielo, James S. 2009. Words upon the Word: An Ethnography of Evangelical Group Bible Study. New York: New York University Press.

Bronfenbrenner, Urie. 1979. The Ecology of Human Development. Cambridge: Harvard University Press.

Chinn, Clark A., Richard C. Anderson, and Martha A. Waggoner. 2001. Patterns of discourse in two kinds of literature discussion. Reading Research Quarterly 36: 378-411. [CrossRef]

Copenhaver, Jeane F. 2001. Listening to their voices connect literary and cultural understandings: Responses to small group read-alouds of "Malcolm X: A Fire Burning Brightly". New Advocate 14: 343-59.

Duke, Nell K., and P. David Pearson. 2002. Effective Practices for Developing Reading Instruction, 3rd ed. Newark: International Reading Association, pp. 205-42.

Eagleton, Terry. 1983. Literary Theory: An Introduction. Minneapolis: University of Minnesota Press.

Eeds, Maryann, and Deborah Wells. 1989. Grand conversations: An exploration of meaning construction in literature study groups. Research in the Teaching of English 23: 4-29.

Fish, Stanley Eugene. 1980. Is There a Text in This Class? Cambridge: Harvard University Press.

Galili-Schachter, Inbar. 2011. Pedagogic hermeneutic orientations in the teaching of Jewish texts. Journal of Jewish Education 77: 216-38. [CrossRef]

Gee, James Paul. 2014. An Introduction to Discourse Analysis. London: Routledge Press.

Greeno, James G. 1997. On claims that answer the wrong questions. Educational Researcher 26: 5-17. [CrossRef]

Hassenfeld, Ziva R. 2017. Teaching sacred texts in the classroom: The pedagogy of transmission and the pedagogy of interpretive facilitation. Journal of Jewish Education 83: 339-66. [CrossRef]

Hassenfeld, Ziva R. Forthcoming. Pursuing fluency in Tanakh: An intervention study in a seventh grade classroom. Journal of Jewish Education.

Haroutunian-Gordon, Sophie. 2009. Learning to Teaching through Discussion: The Art of Turning the Soul. New Haven: Yale University Press.

Katzin, Ori. 2015. Teaching approaches of beginning teachers for Jewish studies in Israeli mamlachti schools: A case study of a Jewish education teachers' training program for outstanding students. Journal of Jewish Education 81: 285-311. [CrossRef] 
King, Pamela E. 2008. Spirituality as fertile ground for positive youth development. In Positive Youth Development and Spirituality: From theory to Research. Edited by Richard Lerner, Robert Roeser and Erin Phelps. West Conshohocken: Templeton Foundation Press, pp. 55-74.

Kress, Gunther. 1997. Before Writing: Rethinking the Paths to Literacy. London: Routledge.

Lehmann, Devra. 2008. Calling integration into question: A discourse analysis of English and Humash classes at a Modern Orthodox yeshiva high school. Journal of Jewish Education 74: 295-316. [CrossRef]

Levine, Sarah, and William Horton. 2015. Helping high school students read like experts: Affective evaluation, salience, and literary interpretation. Cognition and Instruction 33: 125-53. [CrossRef]

Lewis, Cynthia. 1993. “Give people a chance": Acknowledging social differences in reading. Language Arts 70: 454-61.

Luhrmann, Tanya M. 2012. When God Talks Back: Understanding the American Evangelical Relationship with God. New York: Vintage.

Mathison, Sandra. 1988. Why triangulate? Educational Researcher 17: 13-17. [CrossRef]

Mariano, Jenni Menon, and William Damon. 2008. The role of spirituality and religious faith in supporting purpose in adolescence. In Positive Youth Development and Spirituality: From Theory to Research. Edited by Richard Lerner, Robert Roeser and Erin Phelps. West Conshohocken: Templeton Foundation Press, pp. 210-30.

McCormick, Kathleen. 1994. The Culture of Reading and the Teaching of English. Manchester: Manchester University Press.

Paley, Vivian Gussin. 1986. On listening to what the children say. Harvard Educational Review 56: 122-31. [CrossRef]

Peshkin, Alan. 1988. God's Choice: The Total World of a Fundamentalist Christian School. Chicago: University of Chicago Press.

Rabinowitz, Peter J. 1985. The turn of the glass key: Popular fiction as reading strategy. Critical Inquiry 11: 418-31. [CrossRef]

Rabinowitz, Peter J. 1987. Before Reading: Narrative Conventions and the Politics of Interpretation. Ithaca: Cornell University Press.

Reznitskaya, Alina, Richard C. Anderson, Brian McNurlen, Kim Nguyen-Jahiel, Anthi Archodidou, and So-Young Kim. 2001. Influence of oral discussion on written argument. Discourse Processes 32: 155-75. [CrossRef]

Rosenblatt, Louise M. 1995. Literature as Exploration. New York: The Modern Language Association of America. Segal, Aliza, and Zvi Bekerman. 2009. What is taught in Talmud class: Is it class or is it Talmud? Journal of Jewish Education 75: 19-46. [CrossRef]

Vygotsky, Lev. 1978. Mind in Society: The Development of Higher Psychological Processes. Cambridge: Harvard University Press.

Wimsatt, William K., and Monroe C. Beardsley. 1946. The intentional fallacy. The Sewanee Review 54: 468-88. 